\title{
Study and Practices of IT Specialists Cultivation Mode: A Chinese Independent College Perspective
}

\author{
Zhiwen $\mathrm{Hu}$, Li Zhu, Huaqing Mao \\ Wenzhou University Oujiang College, Wenzhou, China \\ Email: 448766175@qq.com, 38995791@qq.com,mr.maohuaqing@qq.com
}

Received June $4^{\text {th }}$, 2012; revised July $10^{\text {th }}$, 2012; accepted July $19^{\text {th }}$, 2012

\begin{abstract}
Independent college is a courageous exploration for higher educational school running mechanism. However, exploring and practicing the novel IT specialists is the inevitable choice for independent colleges. Therefore, following the guide by the market demand, and making full use of the development of regional industry and advantageous resources of the university's realizable orientation, carrying forward the novel IT specialists cultivation mode positively, which is named "Generals + disciplines + majors + characteristics”, has become a reality orientation for applied talents cultivation.
\end{abstract}

Keywords: Independent College; Information Technology; Talent Cultivation Mode

\section{Introduction}

Independent college is a kind of new higher educational school running mechanism in China since the late 1990s (Zhou, 2003: pp. 1-4), (Mou, 2004: pp. 5-9). As the pioneer of the independent colleges, Oujiang College of Wenzhou University is a full-time comprehensive college approved by the National Ministry of Education. The goal of college is to train high-quality, practical, comprehensive and innovative talents with social responsibility and high economic construction capability (Vorley \& Nelles, 2008: pp. 109-126). And Oujiang College has placed great emphasis on reinforcing the capabilities and innovations of students to improve their comprehensive qualities and employment competitiveness. It is run by a new mechanism and model which is devoted to pioneering education and constructing the talent cultivation mode named "Generals + disciplines + majors + characteristics". The results strongly suggested that this educational mode laid the solid foundation for the leapfrog development of disciplines.

Information Technology (IT) and relevant majors is the most popular major in domestic universities and colleges, and the homogeneity of talents cultivation mode is arising. With the rapid expansion of IT, the differences between the intensions and extensions of the IT, which were coined in ten years ago, cause the gap between comprehensive qualities of the graduates and the market demand. And this gap is widening even as the pace of the information age accelerates in society day by day. On the other hand, the quantity of the graduate candidates in IT and relevant majors is hardly to meet the demand of information industry. Absolutely, indefatigable efforts should be made to bridge that gap.

Therefore, with the "quality survival, characteristics and development" education philosophy, it is practical significant to stick to exploring and constructing the new IT talent cultivation mode which includes macroscopic thinking and strategic research, planning the development seriously, charting out the future scientifically and renewing conceptions integrated with practice.

\section{Opportunities and Challenges of Constructing the New Talent Cultivation Mode}

Independent college is secondary college of undergraduate level run by the new mechanism and mode. However, like the other new things, the independent college is affected by social environment, relative law and self-asserting element. There are lots of difficulties and contradictions in development of Oujiang College, such as: following the school-running pattern of Wenzhou University, shaky foundation of education resources and attention on theory but inadequate with the practice. It is necessary to study and resolve those difficulties and contradictions, and promote the leap-forward development college.

During the exploration and construction, the challenges and dilemmas are existing as following: 1) Major setting and constructing lack of characteristics which causes the Oujiang College development guideline is the same with the Wenzhou University. The major setting is dispersed by the disciplines, and there are seven majors belonging to engineering, science and management respectively. The structure and layout of those majors are not reasonable and suitable for the social development; 2) The closed operation is detached from the market demand; 3 ) The backward course setting is out of step with ability training; 4) Lacking of high quality education resources; 5) It causes the dependence of Wenzhou University and the restriction of teachers. Oujiang College has few education features of comparative advantage.

In the meantime, there are unprecedented chances for talent cultivation mode caused by the flexible operation and decision mechanisms of independent college which includes: 1) encourages the general education and innovative education to be the motive force and reality orientation of the independent college; 2) Resolve the structural imbalance between the police power and academic power and conflicts of teachers; build up the input, output and feedback mechanisms of decision information; construct the participatory decision-making mechanism on network for teacher to participate in the administration (Qiu, 2009: pp. 82-85); 3) The internal motive and external need of local uni- 
versity to serve the societal function which is an inevitable choice of independent college is named "school-enterprise collaboration, combination of working and learning”; 4) Regard the employment work as life-blood of independent college development, and construct the employment guidance system in the cultivation mode (Gao, 2008: pp. 81-82).

\section{Construction and Practice of IT Talent Cultivation Mode}

1. Construction of "Generals + disciplines + majors + characteristics” IT talent cultivation mode (Figure 1).

The so-called "Generals + disciplines + majors + characteristics" IT talent cultivation modes means the general education and innovative education is proposed according to the IT talent ability requirement which is "solid academic foundation, great ability, high quality, good at innovating". The mode is based on "common foundation platform, major foundation platform, discipline platform, practical training platform" and regards practical innovation as storyline, which emphasizes on majors construction, and insists on "school-company cooperation, working and learning combination" to construct the general courses group, discipline foundation courses group, professional courses group and particular courses group. The mode divides the four years undergraduate education into three phrase: first two yeas is first phrase and the target is lay a firm foundation by the discipline; the third year is second phrase which the goal is training by the special disciplines, the last year is third phrase including multiple synthesize curriculum design, short term training, field work, social practice, graduation field work, graduation project. Those practical sections make student participate the practical application and improve their ability to analyze and solve problems (Zhou, 2010: pp. 151-154).

Since August, 2009, the principle for Oujiang College is to reform the original major, build up the priority major and explore the particular major. The college optimized the original major which puts the emphasis on two major and one particular school. Right now Oujiang College has Wenzhou key discipline "Computer Science and Technology”, Oujiang College key discipline "Electronic and Information Engineering", Microsoft IT academy, Wenzhou information security infrastructure facilities (Wenzhou information security evaluation center, Wenzhou information security research center, Wenzhou information security training center), Wenzhou University information security research institute. Those organizations provide a powerful guaranteed IT talent cultivation mode. In addition, colleges set up a high-quality teaching faculty to apply the talent cultivation mode.

2. Taking employment as our orientation, design the application talent cultivation solution.

To explore the new IT personnel training mode, the first step is to establish a set to confirm the high-quality information technology IT talents training program according to the needs of the industry and progress of science and technology update. Therefore, we have the original training program that was redesigned and improved according to the subject, by setting the professional direction of traditional thinking and regional economy, the talent market in close connection with the road, according to the employment demand to set up professional direction, and along with the needs for social and technology development, timely updated professional direction and content of the course. The students choose their own direction, and fully embody the principle of "teach students in accordance with their aptitude"

\begin{tabular}{|c|c|c|c|c|}
\hline $\begin{array}{l}\text { Offshore } \\
\text { Outsourcing }\end{array}$ & E-commerce & $\begin{array}{l}\text { Information } \\
\text { Security }\end{array}$ & \begin{tabular}{|c|} 
IT Urgently \\
needed \\
personnel \\
\end{tabular} & \multirow{9}{*}{$\begin{array}{c}\text { IT talent } \\
\text { cultivation } \\
\text { mode } \\
\text { system }\end{array}$} \\
\hline \multicolumn{4}{|c|}{ Character of College } & \\
\hline \begin{tabular}{|c|} 
Career \\
Development \\
Planning \\
\end{tabular} & $\begin{array}{l}\text { Occupational } \\
\text { Guidance }\end{array}$ & $\begin{array}{l}\text { Occupational } \\
\text { Convoy }\end{array}$ & $\begin{array}{l}\text { Occupational } \\
\text { Tracing }\end{array}$ & \\
\hline $\begin{array}{l}\text { Management } \\
\text { Team }\end{array}$ & $\begin{array}{l}\text { Project } \\
\text { Practice }\end{array}$ & $\begin{array}{l}\text { Examination } \\
\text { Evaluation }\end{array}$ & $\begin{array}{l}\text { Qualification } \\
\text { Examination }\end{array}$ & \\
\hline \multicolumn{4}{|c|}{$\begin{array}{l}\text { School-company cooperation, Working and learning } \\
\text { combination }\end{array}$} & \\
\hline $\begin{array}{c}\text { General } \\
\text { Course } \\
\text { Group }\end{array}$ & $\begin{array}{l}\text { Major } \\
\text { Course } \\
\text { Group } \\
\end{array}$ & \begin{tabular}{|c|} 
Disciplines \\
Course \\
Group \\
\end{tabular} & $\begin{array}{c}\text { Particular } \\
\text { Course } \\
\text { Group }\end{array}$ & \\
\hline $\begin{array}{c}\text { Code } \\
\text { Template } \\
\text { Library } \\
\end{array}$ & $\begin{array}{c}\text { Document } \\
\text { Template } \\
\text { Library } \\
\end{array}$ & \begin{tabular}{|c|} 
Configure \\
Management \\
Library \\
\end{tabular} & $\begin{array}{c}\text { Evaluation } \\
\text { Library }\end{array}$ & \\
\hline \begin{tabular}{|c|} 
Standard \\
Specification \\
Library \\
\end{tabular} & $\begin{array}{c}\text { Special } \\
\text { Technical } \\
\text { Library } \\
\end{array}$ & $\begin{array}{c}\text { Education } \\
\text { Resource } \\
\text { Library } \\
\end{array}$ & $\begin{array}{c}\text { Practical } \\
\text { Example } \\
\text { Library }\end{array}$ & \\
\hline $\begin{array}{c}\text { Common } \\
\text { Foundation } \\
\text { Platform } \\
\end{array}$ & $\begin{array}{c}\text { Major } \\
\text { Foundation } \\
\text { Platform } \\
\end{array}$ & $\begin{array}{c}\text { Discipline } \\
\text { Foundation } \\
\text { Platform }\end{array}$ & $\begin{array}{c}\text { Practical } \\
\text { Foundation } \\
\text { Platform } \\
\end{array}$ & \\
\hline
\end{tabular}

\section{Figure 1.}

IT talent cultivation mode for Wenzhou University Oujiang College.

according to their own interest and level, through the selection of courses arrangement and the professional direction.

In the process of course construction with the curriculum group construction as the main line, the exquisite courses and the key courses drive general curriculum construction. According to the "core stability, flexible direction" train of thought, professional core curriculum group of computer and electronic information according to the basic theory of knowledge system, tamp foundation, relatively stable, prevent the students future development from the "aftereffect inadequacy". Professional direction and the curriculum are market demand-oriented, and reflect the employment market for IT application type talents knowledge structure requirements. We should emphasize practical ability and practical ability, pay attention to occupation attainment and skills training and exercise according to the employment and flexible setting so as to enhance students' adaptability. Core curriculum construction focuses on the renewal of the teaching content, teaching method, teaching means in particular and the reform of evaluation mode. Professional direction and courses setting should be flexible to respond to market changes and update timely. Advanced design of the teaching content not only provides students with a complete knowledge structure, but also satisfies the needs of students' development.

3. Taking requirement as our orientation, construct the "multiple layer and integration” practical teaching system.

In order to make the graduates to serve the community better, we need to cultivate the students' ability to analyze and solve the problems, and the teaching model should be translated from knowledge to ability, avoid "to fight only on paper" and strengthening the link of practice.

In practice, we always adhere to make reform and innovation of the practice teaching as the main line. During the curriculum setting and the teaching design, we emphasize applications, cultivating students' practical ability in practice. Therefore, we need to design a multi-level and integrated practice teaching system, which consists of "unit experiment, comprehensive experiments, 
short term training, graduation practice and graduation design”. Also, we will ensure sufficient practice credits/hours. At the same time, we will carry out various academic competitions, students' research projects and other extra curricular activities. The practice credits are accounted for a reasonable proportion of the professional education credits. In the professional core courses and the modules of specialty orientation course, the proportion for experimental teaching hours and the theory hours are reasonable.

According to the idea of "from the demand to push", the practice teaching link has undertaken comparative comprehensive reformation as following through the construction of "four platform eight base":

1) The reformation of practice link for the professional core courses focuses on training programming ability and other basic skills, emphasizes standardization of the experimental link. Each course is planned by the person in charge of course system, which is a clear target in experimental teaching outline; the requirement and content for experiments unit are standardized according to the experimental guidance, which promises culture foundation and the promotion of integrated design, encourages research and innovation, and promotes the teaching methods and means of reformation;

2) The reformation of the practice for professional direction module courses focuses on training students' comprehensive design ability. In addition to unit experiments, each course includes comprehensive design experiments, which aims at digesting all the contents of the course. The association between professional courses is relatively strong. The actual development of the projects requires integration of multiple knowledge. Therefore we need to design a project associated with various courses, and this will make the student acquire the ability of analyzing and solving problems;

3) Short term training. Short term training is combined with professional direction of the students, which is accordance with the mode of "project drive, team cooperation". Through simulation of projects development, the students will master the learned knowledge, inspire innovative ideas and skills training, raise abilities including independent analysis, practice, communication, teamwork and project management;

4) Graduation practice and graduation design. Graduation practice and graduation design are respectively arranged in the final year. The subject of the graduation design is further deepened than graduation practice, of which the objective is to train comprehensive use of the knowledge and ability to solve the practical problems of the students. It also improves the comprehensive quality of the students and lays a good foundation for employment. The students can participate in research project of the teachers or participate in the actual project development in the relevant enterprises, or practice in practice base with cooperation established between school and enterprise. Through these actual exercises, the students will not only use knowledge flexibly, but also accumulate practical experience. It also improves practical ability, thus narrowing the distance to requirement of enterprise, which creates good condition for high salary employment. In order to strengthen management and establish information platform for the graduation practice/graduation, we should monitor effectively from topic choosing to graduation reply. Also, we equip with "Double Teachers" for the students who finish their graduation design out of school, and that is to say the students are guided by the professional teachers and technical staffs. This method will help the student to improve the structure of knowledge and practical application ability, finally become the applied talents of engineering with solid foundation. The teaching mode is featured with teachers guiding students, students' cooperation, and the communication between teachers and students.

4. The mode of combination involving production, teaching \& research will enhance adaptability and practicability of talent cultivation in multiple channels.

The college cultivates students in closed or semi-closed mode often has some gap with the requirement of the enterprise. The enterprises need the experienced staffs, but the graduated students are lacking in experience precisely. This phenomenon is obvious in supply and demand of the IT talents. In order to cultivate the applied talents, "school-enterprise cooperation, combining learning with working" is the route one must follow. The main ways for combination involve production, teaching \& research including enterprise customization and attracting the students participating in the research projects of the teachers.

The modes including cooperation with enterprises to establish practice base and customization talent cultivation at the stage of graduation practice/graduation design take full advantages in both college and enterprises. The college can cultivate the students according to requirements, such as "the unitary training", "talent classification cultivation"; The enterprise can import enterprise culture, technology and other aspects of the requirements into process of the teaching in advance and training technical personnel for their own needs.

Talent cultivation customization makes our graduates directly meet the needs of the enterprises so that the students meet the requirements of the enterprises and the enterprises will have qualified talents. Therefore it leads to a win-win situation, which will strengthen the adaptability and practicability of talent cultivation, realize the successful connection between talent cultivation and social needs, and reach the target of application talent cultivation.

We will directly cooperate with the enterprises through teacher's scientific research activities to promote the cultivation of application talents. Firstly, we need to establish a good scientific research environment for teachers, through a number of young teachers of rich practical experience, at the completion of teaching tasks at the same time, to undertake the enterprise scientific research item. Secondly, we need encourage students to participate in teachers' research projects actively, and the ability of students will be largely improved by taking part in the actual project, and the learning initiative and enthusiasm of the students are also improved The students with practical development experience can get more favor of the enterprise and will realize interaction between teachers' research and development of engineering application talents.

5. Characteristic Concise, deepening reformation of talents training mode.

In recent years, we focus on the goals of training and employment, and the Institute insists ideas of "enterprise cooperation, combining learning with working”, which broadens their educational ideas and expands the channels of education and we have achieved good results.

On February 24, 2009, Oujiang College and Microsoft China developed talents of service outsourcing. In July, 2010, Microsoft IT Academy was included in the "international service outsourcing talents cultivation base of Zhejiang province”. On December 23, 2009, three centers of information security in Wenzhou as three information security infrastructures are settled in 
our college, whose purpose is to provide information security services for the local Wenzhou, and train skilled high-end talents to meet growing demand of talents for the information security field.

Nowadays, relying on the Microsoft IT Academy, Taobao characteristic class, "Zhejiang international service outsourcing talent training demonstration base", "international certification test center, three centers" of "Wenzhou information security", national information technology tight talents training project, we cultivate advanced applied talents who are suitable for outsourcing services, e-commerce, information security, smart appliances and other industries; relying on the "employment escort assurance plan docking base”. We guarantee the students to be employed successfully. The initial employment rate of the graduates in 2010 reached 97.778\%; 47 graduates of 2011 (approximately $1 / 4$ of the total graduates ) had accessed to the plan of "high road" "pre-job training" and acquired professional employment, and the salary is not less than 3500 yuan a month, which has formed relatively obvious features of running a school. The new personnel training mode obtains acknowledgement of the students, parents and the community, and at the same time, it was also paid sustain attention on by authoritative media such as people media.

\section{Safeguard Mechanism for Information Technology Talent Cultivation Model}

In order to standardize the application personnel training work, we form a relatively completive set of management mechanism. In daily teaching operation, we have made relevant documents and regulations system decompose the teaching tasks in detailed, and assure that each work is carried on methodically.

We also have established the multi-level teaching management system of the "college-branch of the college-professsional-course group". According to the plan of talent training, we set up a certain number of curriculum group, and each organization will take the backbone teacher as the person in charge, who is responsible for the coordination of daily teaching work and teaching reform.

The teacher will participate in relevant organizations, implement dynamic management and set up educational supervision to monitoring quality of teaching and help the teachers to improve teaching quality in time. The teaching management team is keen-witted, capable, efficient, diligent and responsible, and full of innovative awareness, which is willing to provide teachers and student with good services. At the same time on completion of teaching tasks, the college need actively guide and sup- port the teachers to take part in teaching research and teaching reform, which will create good environment for teaching reform and innovation.

\section{Conclusion}

Based on the actual situations of the students, combining characteristics of area and professionals, we will focus on the growth of the students, take "academic, employment, and entrepreneurship" as the main line, take "education, management and service" as the means, "take grasp quality inside, outside the plastic image" as the carrier. There still has been a long way to go for cultivating information technology talents with unique style of Oujiang College. But we will make the "three-chuang” talents as the goal, through the concept of innovative personnel training to construct training mode systematically. The train mechanism, quality monitoring system, especially agreement with situation of the independent college, are actively explored and practiced on "Generals + disciplines + majors + characteristics" information technology talents cultivation model, which provides references and examples for the talents cultivation for independent colleges.

\section{Acknowledgements}

This work was supported by a grant from Zhejiang province college lab research project: Research on construction trinity of network and information security lab (Grant No. Y201236).

\section{REFERENCES}

Gao, H. X. (2008). In the construction of college platform training mode of complete process employment guidance system. Pioneering with Science \& Technology, 3, 81-82.

Mou, Y. C. (2004). Independent college-A new round development of historic choice for China's higher education. Exploring Education Development, 4, 5-9.

Qiu, X. Y. (2009). The difficulties of decision-making and mechanism innovation for teachers in college. Exploring Education Development, 3, 82-85.

Vorley, T., \& Nelles, J. (2008). Conceptualising the academy: Institutional development of and beyond the third mission. Higher Education Management and Policy, 3, 109-126.

Zhou, J. (2003). Promote healthy and rapid development of the independent college. Exploring Education Development, 8, 1-4.

Zhou, H. S. (2010). Study on practice teaching of computer science and technology of independent college. Computer Education, 12, 151-154. 